\title{
A repetitív transcranialis mágneses stimuláció szerepe a mentális zavarok, elsősorban a terápiarezisztens major depresszív zavar kezelésében
}

\author{
Pilisi Róbert dr. ${ }^{1}$ - Tényi Tamás dr. ${ }^{1}$ - Büki András dr. ${ }^{2}$ \\ Kovács Norbert dr. ${ }^{3}$. Zemplényi Antal dr. ${ }^{4}$. Sebestyén Gabriella ${ }^{2}$ \\ Osváth Péter dr. ${ }^{1}$ - Fekete Sándor dr. ${ }^{1}$ - Vörös Viktor dr. ${ }^{1}$ \\ ${ }^{1}$ Pécsi Tudományegyetem, Általános Orvostudományi Kar, Klinikai Központ, \\ Pszichiátriai és Pszichoterápiás Klinika, Pécs \\ ${ }_{2}^{2}$ Pécsi Tudományegyetem, Általános Orvostudományi Kar, Klinikai Központ, Idegsebészeti Klinika, Pécs \\ ${ }^{3}$ Pécsi Tudományegyetem, Általános Orvostudományi Kar, Klinikai Központ, Neurológiai Klinika, Pécs \\ ${ }^{4}$ Pécsi Tudományegyetem, Gyógyszerésztudományi Kar, Gyógyszerészeti Intézet, \\ Farmakoökonómia Tanszék, Pécs
}

\begin{abstract}
A repetitív transcranialis mágneses stimulációs eljárás egy olyan neuromodulációs technika, melynek gyorsan fejlődő területe jelentheti az egyik biztonságos, alternatív megközelítési módot bizonyos mentális zavarok, elsősorban a terápiarezisztens major depresszív zavar kezelésében. Célunk a transcranialis mágneses stimulációs kezelés jelenlegi kutatási és klinikai alkalmazási lehetôségeinek bemutatása a szakirodalmi adatok és a klinikai gyakorlat áttekintése alapján. Mióta ismertté vált, hogy külsô mágneses forrással neuronok depolarizálhatók, mind a neurológia, mind a pszichiátria az eljárás lehetséges klinikai használatát kutatja. Napjainkig a módszer a pszichiátria területén belül a major depresszív zavar és a kényszeres zavar kezelésében engedélyezett, de egyéb betegségek (például szkizofrénia, bipoláris zavar) kezelésében is kutatják lehetséges alkalmazását. A transcranialis mágneses stimulációs rendszerek fejlesztésének következő lépcsőjét jelenti a mágnesesrezonancia-felvétel alapján, helymeghatározó algoritmusok segítségével, valós időben navigált mágneses stimulációs készülékek kidolgozása. Az úgynevezett neuronavigációs rendszerek lehetővé teszik a depresszió kialakulásáért felelős idegi hálózatok pontos célzását, így a dorsolateralis praefrontalis kéreg excitabilitásának fokozását a bal féltekén és csökkentését a jobb féltekén. Az eljárás kevés kontraindikációval bír, és a megfelelő körültekintéssel választott indikáció és betegpopuláció esetén mellékhatások is alacsony számban jelentkeznek. A transcranialis mágneses stimulációs kezelés mára bizonyítottan hatékony módszerré vált bizonyos mentális zavarok, elsősorban a terápiarezisztens major depresszív zavar kezelésében. A jövőben a neuronavigációs neuromodulációs kezelések, azon belül is a repetitív transcranialis mágneses stimulációs kezelés térhódítása várható a pszichiátria és a neurológia területén. Jelenleg Magyarországon több centrumban is végeznek különböző indikációkban mágneses stimulációs kezeléseket, ám az eljárás mentális zavarokban történő alkalmazásának finanszírozási befogadása és beépítése a mindennapi klinikai gyakorlatba még várat magára.
\end{abstract}

Orv Hetil. 2020; 161(1): 3-10.

Kulcsszavak: transcranialis mágneses stimuláció, neuromoduláció, neuronavigáció, major depresszív zavar

\section{The role of repetitive transcranial magnetic stimulation in the treatment of mental disorders, especially in treatment-resistant major depressive disorder}

The rapidly evolving field of repetitive transcranial magnetic stimulation as a neuromodulational technique may mean a safe, alternative approach to the management of several mental disorders, especially treatment-resistant major depressive disorder. Our aim is to describe the current role of transcranial magnetic stimulation in research and routine clinical practice, based on the literature and clinical protocols. Since the discovery, that an outer magnetic source can depolarize neurons, both neurology and psychiatry seek the method's possible clinical utility. To date, in the field of psychiatry, the method is only approved in the treatment of major depressive disorder and obsessive-compulsive 
disorder, but research continues to find application in other mental disorders (schizophrenia, bipolar disorder), too. The next step in the evolution of repetitive transcranial magnetic stimulation is based on magnetic resonance guided, real-time navigation with the help of positioning algorithms. The so-called neuronavigational systems make precise aiming of neuronal circuits responsible for the development of depression, thus increasing the excitability of the left dorsolateral prefrontal cortex and decreasing it on the right hemisphere. The method has few contraindications, and the occurrence of side effects can be minimized by carefully selected patient population. For today, transcranial magnetic stimulation became an evidence-based, effective treatment for some mental disorders, especially treatment-resistant major depressive disorder. It is to be assumed that in the future neuronavigational neuromodulation techniques, including repetitive transcranial magnetic stimulation, will be widely used in the field of psychiatry and neurology. Magnetic stimulation is currently available in a number of centres in Hungary, but the financial approval and the implementation of this neuromodulation method for treating mental disorders in the everyday clinical practice are still in progress.

Keywords: transcranial magnetic stimulation, neuromodulation, neuronavigation, major depressive disorder

Pilisi R, Tényi T, Büki A, Kovács N, Zemplényi A, Sebestyén G, Osváth P, Fekete S, Vörös V. [The role of repetitive transcranial magnetic stimulation in the treatment of mental disorders, especially in treatment-resistant major depressive disorder]. Orv Hetil. 2020; 161(1): 3-10.

(Beérkezett: 2019. augusztus 9.; elfogadva: 2019. szeptember 20.)

\section{Rövidítések}

$\mathrm{ACTH}=$ (adrenocorticotropic hormone) adrenokortikotrop hormon; APA $=($ American Psychiatric Association $)$ Amerikai Pszichiátriai Társaság; CANMAT = (Canadian Network for Mood and Anxiety Treatments) Kanadai Hálózat a Hangulati és Szorongásos Zavarok Kezeléséért; CRH $=$ (corticotropinreleasing hormone) kortikotropinfelszabadító hormon; DBS = (deep brain stimulator) mély agyi stimulátor; DLPFC $=($ dorsolateral prefrontal cortex) dorsolateralis praefrontalis kéreg; FDA $=($ Food and Drug Administration $)$ az Egyesült Államok Élelmiszer-biztonsági és Gyógyszerészeti Hivatala; HDRS = (Hamilton depression rating scale) Hamilton-féle depresszióértékelő skála; MADRS = (Montgomery-Åsberg depression rating scale) Montgomery-Åsberg-féle depresszióértékelő skála; $\mathrm{MDZ}=$ major depresszív zavar; $\mathrm{MR}=$ mágneses rezonancia; $\mathrm{MT}=$ (motor threshold) motoros határérték, motoros küszöb; NICE $=($ National Institute for Health and Care Excellence $) \mathrm{az}$ Egyesült Királyság Nemzeti Egészségügyi és Ellátó Intézete; PTSD $=$ (post-traumatic stress disorder) poszttraumás stressz zavar; ROI $=$ (region of interest) vizsgálati terület; rTMS = repetitív transcranialis mágneses stimuláció; $\mathrm{STAR}^{*} \mathrm{D}=$ (Sequenced Treatment Alternatives to Relieve Depression) Szekvenált Kezelési Alternatívák Depresszió Kezelésére; TBS = (theta burst stimulation) théta-frekvenciájú ingerlés; TMS = transcranialis mágneses stimuláció; TRD = terápiarezisztens depresszió; WFSBP $=($ World Federation of Societies of Biological Psychiatry) Biológiai Pszichiátriai Társaságok Világszövetsége

Összefoglaló tanulmányunkban a transcranialis mágneses stimuláció (TMS) elméleti alapjait és klinikai alkalmazási lehetőségeit tekintjük át. Mivel az utóbbi években egyre több közlemény bizonyította a repetitív transcranialis mágneses stimuláció (rTMS) pozitív hatását különböző neurológiai és pszichiátriai betegségekben, elsősorban major depresszív zavarban (MDZ),
2008 októberében az amerikai Food and Drug Administration (FDA) jóváhagyta a rTMS-t mint neuromodulácós terápiát azon MDZ-ban szenvedő felnőtt betegek kezelésére, akik legalább egy, megfelelő ideig és megfelelő dózisban alkalmazott antidepresszív kezelésre nem reagáltak megfelelően. Azóta számos szakmai irányelv és klinikai útmutató (például az APA, CANMAT, NICE, WFSBP) igazolta és javasolja a rTMS-kezelést különböző depressziós állapotokban, ám a legoptimálisabb eredmény eléréséhez és a további specifikumok meghatározásához (specifikus betegpopuláció, kezelési technikák stb.) további klinikai vizsgálatok szükségesek. Az eddig összegyúlt vizsgálati eredmények alapján azonban már kijelenthető, hogy a rTMS korunk egyik sikerrel kecsegtető megközelítése lehet a terápiarezisztens depresszióban (TRD) szenvedő páciensek kezelésében is. Ugyanakkor a hazai gyakorlatban az eljárás még nem terjedt el, tekintettel részben a hazai finanszírozási befogadás hiányára is. Reményeink szerint ez a gyakorlat hamarosan megváltozik, és hazánkban is széles körben alkalmazhatóvá válik ez az evidenciákon alapuló kezelési eljárás. Részben a fentiek elősegítése érdekében készítettük az alábbi szakmai összefoglalót, melyben a TMS múködési elvének, hatásmechanizmusának rövid bemutatását követően a fó indikációs területeket, valamint a kontraindikációkat és mellékhatásokat vázoljuk fel, majd a kiegészítő terápiás lehetőségeket, valamint a TMS-kezelés gyakorlati szempontjait és jövőbeli alkalmazási területeit is ismertetjük.

\section{Müködési elv}

Az első, klinikai szempontból használható TMS-készülék 1985-ben készült. A rTMS múködési elve Faraday indukciós törvényén alapszik: az elektromos áram maga 
körül mágneses mezőt generál, és fordítva; mágneses mezővel elektromos áram gerjeszthető egy vezetőkörben. A jelen esetben a vezetőkört az emberi agy jelenti. A TMS-készülék mágneses ingerlésért felelős tekercsében szabályozott elektromos árammal időben változó mágneses mező generálható, melynek hatására a cortexben elektromos áram indul meg, ami depolarizációhoz vezet [1]. A motoros kiváltott válaszra irányuló vizsgálatok során egyértelmúvé vált, hogy az alkalmazott mágneses ingerlés a neuronok excitabilitását képes akár percekig megváltoztatni [2]. Az alkalmazott tekercs formájától függően változik a mágneses mező alakja, így eltérő alakú tekercsek eltérő nagyságú területet fognak depolarizálni. A legelterjedtebben használt tekercs a nyolcas alakú tekercs, mely a legpontosabb célzást teszi lehetővé, de létezik ezen kívül a nagyobb területet ingerlö H-tekercs is, illetve a mára elavulttá vált gyưrütekercs [3]. Az alkalmazott mágnesesfluxus-sûrüség (melyet teslában [T] mérünk) a szöveti penetráció mértékét határozza meg. Egy átlagos nyolcas tekercs 1,5-2,5 T mellett 2-3 cm mélyen fejti ki aktiváló hatását a legerősebben [4]. A nagyobb mélységbe (akár $6 \mathrm{~cm}$ mélyre) hatoló $\mathrm{H}$ tekercs képes mélyebb neuronhálózatokat is ingerelni, ám célzásban pontatlanabb [5]. Fontos kiemelni, hogy a terápiában használt, egymás után sok impulzus leadására képes tekercsek (rTMS) esetében az elektromos ellenállásból fakadóan jelentős hőmérséklet-emelkedéssel kell számolni, így ezen készülékek beépített hütőrendszerrel bírnak, mely levegőt vagy hütőfolyadékot keringtet a tekercsben.

A TMS-készülékek fejlesztésével lehetőség nyílt ismételt impulzusok leadására, akár $50 \mathrm{~Hz}$-es tartományban (50 ingerlés másodpercenként). Ha az alkalmazott frekvenciatartomány alacsony ( $1 \mathrm{~Hz}$ vagy az alatt), úgy a cortexben a kiváltott motoros válaszok amplitúdója mérséklődik, tehát az excitabilitást csökkenti, inhibitorhatással bír [6]. Ennek ellenkezője is igaz, a magas frekvenciatartományú ( $5 \mathrm{~Hz}$ vagy a fölött) mágneses ingerlés potencírozza a kiváltott motoros válaszokat, a kérgi ingerlékenységet növeli [7].

\section{Hatásmechanizmus}

A fenti eredmények ismeretében kutatások indultak azon célból, hogy a TMS-készülékeket átültethessék a klinikai használatba. Ahogy a depresszió kialakulása mögött meghúzódó neuroanatómiai eltérések ismeretanyaga egyre részletesebb lett, úgy merült fel a mágneses stimuláció mint lehetséges kezelési mód. A depresszió nem egyetlen körülírt neuroanatómiai struktúra laesiójának feleltethető meg, hanem egy komplex neuronhálózat patológiás múködése vezet a tünettan kialakulásához. A képalkotó, az elektrofiziológiai és a neurobiológiai kutatások során egyfajta központi idegrendszeri „depresszióhálózat” körvonalazódott [8]. A depresszió patofiziológiájának funkcionális képalkotó eljárásokkal történó kutatása többek között a bal dorsolateralis praefrontalis kéreg (DLPFC) csökkent metabolikus aktivitását és véráramlását mutatta ki, ami a depressziós tünettan sikeres kezelését követően normalizálódott [9]. Depresszió fennállása esetén a jobb oldali praefrontalis régió növekedett aktivitása szintén szerepet játszhat a központi idegrendszerben megfigyelhető funkcionális eltérések között [10]. A bal DLPFC magas frekvenciájú ingerlése mellett ezen területek aktivitása normalizálódott [11], és hasonló hatást figyeltek meg a jobb DLPFC inhibitoros (alacsony frekvenciájú) ingerlése mellett is [12]. A depresszió tüneteiért felelős központi idegrendszeri hálózat feltérképezése további lehetséges terápiás célpontokkal szolgálhat. Jelenlegi ismereteink szerint a hangulati állapot szabályozásában kitüntetett szerepe van az orbitofrontalis, a medialis praefrontalis és az anterior cingularis cortexnek is [13]. Különösen az anterior cingularis kéreg területén található Brodmann 24-es, 33-as és a subgenualis cingulum (Brodmann 25-ös) régiók hozhatók összefüggésbe az érzelmi hangoltsággal, amit képalkotó vizsgálatokkal is igazoltak [14].

Állatkísérletek tanulsága szerint a rTMS-kezelés, amennyiben a praefrontalis kérgen végzik, növeli mind a szerotonin, mind a dopamin koncentrációját a praefrontalis területeken, a hippocampusban és a striatumban [15]. A TMS-kezelés normalizálhatja a hypothalamushypophysis-mellékvese-tengely múködését, valamint csökkentheti a kortikotropinfelszabadító hormon $(\mathrm{CRH})$ és adrenokortikotrop hormon (ACTH) termelödését, így hatásában hasonlít a farmakológiai antidepresszív terápiára [16]. A rTMS-terápiának a depresszió kezelésében játszott szerepében lehetséges hatásmechanizmusként jelenik meg a kezelés kimutatott neuroprotektív hatása, melyet az oxidatív stressz csökkentésén keresztül fejthet ki [17].

\section{Engedélyezés, költséghatékonyság}

A rTMS-kezelés FDA általi engedélyezése a depresszió terápiájára 2008-ban megtörtént. Az engedélyezés egy 2007. évi placebokontrollált, kettős vakvizsgálaton alapult, melynek során 301, pszichotrop gyógyszert nem szedő, major depresszióval diagnosztizált pácienst kezeltek, akiknél a gyógyszeres terápia nem bizonyult hatékonynak. A páciensek 6 héten keresztül, heti 5 alkalommal részesültek kezelésben 120\%-os motorosküszöb (MT)-érték mellett, alkalmanként 3000 impulzust leadva. A késóbbiekben ezek a beállítások váltak az ajánlott standarddá. A kutatás során az eredményeket a Montgomery-Åsberg-féle depresszióértékelő skála (MADRS) és a Hamilton-féle depresszióértékelő skála (HDRS) segítségével vizsgálták. Az eredmények szignifikáns javulást mutattak a rTMS-kezelésen átesett pácienseknél. A vizsgált csoport 4,5\%-a nem fejezte be a kezelést a tapasztalt mellékhatások (fóleg fejbőri fájdalom) miatt [18].

Az FDA által terápiában először engedélyezett TMSkészülék a NeuroStar TMS Therapy System (Neuro- 
netics, Malvern, PA, Amerikai Egyesült Államok) volt. Azóta különböző indikációs területeken további készülékek kerültek engedélyezésre az illetékes amerikai, valamint európai hatóságok által (például a Deep TMS System, Brainsway, Jeruzsálem, Izrael; Rapid Therapy System, Magstim, Whitland, Egyesült Királyság; MagVita Therapy System, MagVenture, Koppenhága, Dánia; NeuroSoft TMS, Ivanovo, Oroszország; Nexstim, Helsinki, Finnország; stb.) [19]. Ezek mellett létezik az úgynevezett mély agyi TMS-kezelés, mely akár $6 \mathrm{~cm}$ mélységig képes modulálni az agyi aktivitást. Ezen eljáráshoz a már említett H-tekercset használják, mely nagy kiterjedésü területen ad le impulzusokat, így a DLPFC pontos célzása nem lehetséges, szemben a nyolcas alakú tekerccsel. Ezt az eljárást szintén engedélyezte az FDA, mivel kimutatták egyértelmű hatékonyságát TRD kezelésében az inaktivált tekerccsel végzett placebokezeléshez képes [20].

Az FDA által engedélyezett protokollok költsége átlagosan 6000 és 12000 USD között ingadozik, ugyanakkor több vizsgálat is rámutatott arra, hogy a farmakoterápiával szemben rezisztens depressziós betegek körében a rTMS-eljárás költséghatékonynak bizonyult [21]. Ma már egyre több költséghatékonysági elemzést végeznek, melyek összességében arra utalnak, hogy a rTMS alkalmazása hosszabb távon költséghatékony megoldás lehet az antidepresszívumra nem megfelelően reagáló páciensek számára [22, 23].

Bár számos TMS-készülék rendelkezik már európai engedéllyel a depresszió kezelésére, a finanszírozási befogadás hiánya hazánkban továbbra is gátat szab szélesebb körü elterjedésének. Továbbá Magyarországon sem a szakmai irányelvekben, sem a tankönyvekben nem szerepel kellő hangsúllyal ez az új, ugyanakkor bizonyítottan hatékony terápiás módszer.

\section{Javallat}

A rTMS-kezeléseket a pszichiátria a MDZ kezelésében hasznosítja a legelterjedtebben. Az FDA ajánlása szerint a rTMS-monoterápia alkalmazható minden, MDZ miatt kezelt felnőtt páciensnél, aki a jelenlegi depressziós epizód során legalább egy orális antidepresszívumra nem reagált kielégítően. A fentiek alapján a rTMS-terápia ígéretes lehetőségnek tünik a TRD-val diagnosztizált betegek számára is. A terápiarezisztens (pontosabban az antidepresszívum-rezisztens) depresszió legelterjedtebb definíciója szerint inadekvát választ jelent major depreszszió miatt kezelt pácienseknél a jelenlegi epizódban megfelelő dózisban és megfelelő ideig alkalmazott legalább két különböző hatásmechanizmusú antidepresszívumra. További szempontot képez a kezelés előtti állapotokhoz képest $50 \%$-os javulást nem elérő változás a depressziót mérő kérdőívekben, illetve a mérhető klinikai válasz érdemleges funkciójavulás nélkül [24]. A depresszió miatt kezelésbe kerülő páciensek harmada nem reagál 1-2 hónapon belül a kezdeti antidepresszív keze- lésre, pedig a korai ellátás fontosságát hangsúlyozza a tény, hogy a depresszió az esetek ötödében krónikus formát ölt, a betegek 50-85\%-a pedig visszatérő depressziós tüneteket tapasztal [25].

A STAR*D-vizsgálat eredményei alapján kulcsfontosságú a gyógyszeres terápia mellett a megfelelő időpont kiválasztása a nem farmakológiai intervencióra, ugyanis a páciensek gyógyszeres terápiával való együttmúködése jelentős romlást mutat az első sikertelen antidepresszív kezelést követően [26]. Ennek függvényében érdemes időzíteni a rTMS-kezelés megindítását, ami 4-6 hetes időtartamával jelentős energiabefektetést követel mind a klinikustól, mind a kezelésben részesülő pácienstôl. A hat hétig tartó rTMS-monoterápia mellett 60\%-os remissziót figyeltek meg, valamint azt, hogy akik kezdetben megfelelően reagáltak a rTMS-terápiára, azok a későbbi relapsusok idején is jó válaszkészséget mutattak [27].

Érdemes kiemelni, hogy 2018-ban az FDA kényszeres zavar kezelésében is engedélyezte a rTMS-terápiát. A jövőben még tovább bővülhet az indikációs terület, hiszen a fentiek (major depresszív zavar, kényszeres zavar) mellett fájdalom esetén (A evidenciaszint - bizonyítottan hatékony), valamint stroke kezelésében (B evidenciaszint - valószínúleg hatékony) is hatékonynak találták. Fülzúgás és akusztikus hallucinációk esetén $\mathrm{C}$ evidenciaszinttel rendelkezik (lehetséges hatékonyság). Egyes vizsgálatok hasznos eszköznek találták továbbá a MDZ mellett a hangulatzavarok egyéb formáiban is, mint például a Parkinson-kórhoz társuló depresszió [28], serdülőkori hangulati zavarok [29], perinatalis depresszió [30] vagy bipoláris zavar [31] esetén, valamint szkizofrénia [32], szorongásos zavarok (pánikzavar, PTSD) és egyéb pszichiátriai kórképek és tünetek (hallucinációk, negatív tünettan, kognitív zavarok) kezelésében is.

A pszichiátriai gyakorlat szempontjából a bipoláris zavarnak (elsősorban depressziós epizódjának) és a szkizofréniának (fóleg negatív tüneteinek, illetve a hallucinációknak) a potenciális kezelése kerülhet elötérbe. Egy 2017. évi kutatás az unipoláris és bipoláris depresszív zavar miatt kezelt páciensek rTMS-kezelését hasonlította össze [33]. A bipoláris depresszió miatt kezeltek 41\%-a mutatott szignifikáns javulást az alkalmazott kezelésre. Összefüggést mutatott a kezelés hatékonyságával a páciensek kora is: unipoláris depresszió esetén a fiatalkorúak nagyobb arányban mutattak javulást, míg bipoláris depresszió esetén hasonló összefüggést nem tapasztaltak. $\mathrm{Az}$ idősebb populáció csökkent válaszkészsége mögött feltételezések szerint a praefrontalis atrophia állhat [33]. Összességében a bipoláris zavar depressziós epizódjának kezelésével kapcsolatban biztatók az eddigi eredmények, ugyanakkor a mániás fázis kezelésével kapcsolatban még nem áll rendelkezésünkre elégséges adat, így további jól kontrollált klinikai vizsgálatok szükségesek a bipoláris zavar rTMS-kezelésének vonatkozásában.

A szkizofrénia negatív tüneteinek kezelésére célzott kutatások során ígéretes célpontnak tűnt a bal DLPFC 
stimulálása. Mágnesesrezonancia (MR)-spektroszkópiával vizsgálták a kezelés előtti és utáni glutamát-, glutamin- és n-acetil-aszpartát-szintet a bal DLPFC-ben, és azt találták, hogy 3 hetes, magas frekvenciájú rTMS-kezelést követően az adott régióban a glutamát koncentrációja megemelkedett, míg a kontrollcsoport esetén csökkent, ám ezen változás nem mutatott összefüggést a tünetek klinikai megjelenésével. A fentiekre tekintettel, bár szignifikáns klinikai javulást nem dokumentáltak, a kezelés hatására bekövetkező neurofiziológiai változások, valamint az egyéb pozitív vizsgálatok alapján előnyösnek tünik a rTMS alkalmazása a szkizofrénia negatív tüneteiben, illetve a hallucinációk csökkentésére, azonban további kutatás javasolt a rTMS-terápia lehetséges szerepének meghatározására a szkizofrénia kezelésében $[32,34]$.

\section{Ellenjavallat, mellékhatások}

A rTMS-kezelés kontraindikációját jelenti az ingerlés helyszínéhez viszonyított $30 \mathrm{~cm}$-es közelségben (vagy a fej-nyaki régióban) elhelyezkedő ferromágneses implantátum (például cochlearis implantátum, fogászati beültetés, gyógyszerpumpa, elektromos ingerlőeszköz), mivel ezen eszközöket a készülék által generált mágneses mező nemcsak roncsolhatja, de fel is melegítheti, ezáltal a környező szöveteket is rongálhatja $[35,36]$. A fentiekből következően a mély agyi stimulátor (DBS) készülék beültetése abszolút kontraindikációt jelent, mivel a készülékben nemkívánatos áramot generál [37]. A fej-nyaki régiónál távolabbi ferromágneses implantátumok nem jelentenek kontraindikációt a mágneses tér korlátozott kiterjedéséból fakadóan [4].

A rTMS-kezelés mellékhatásai közül a leggyakoribb a mágneses stimulálás helyének megfelelő, általában enyhe fejbőri diszkomfort, mely azonban ritkább esetekben tenziós fejfájásnak megfelelő tünetekkel is jelentkezhet. Gyakori diszkomfortot okoz a kezelés idegeket depolarizáló hatása is, mely például a nervus trigeminus ingerlésén keresztül kellemetlen izomrángásokhoz és fájdalomhoz vezethet [38]. A mellékhatások jellegéból fakad, hogy az ingerlőtekercs helyzetének és dőlésszögének változtatásával egy részük kikerülhető. Ritka, de súlyos mellékhatásként jelenik meg a rTMS-kezelés során a görcsküszöb csökkenése következtében kialakuló konvulzió [39]. A kezeléssel kapcsolatosan kialakuló rohamok előfordulásának valószínűsége a klinikus elővigyázatosságával minimalizálható, így a görcsküszöböt csökkentő gyógyszerek kezelés előtti elhagyása javasolt. A görcskészség fokozása szempontjából magas rizikójú gyógyszernek minősülnek egyes antidepresszívumok (például amitriptilin, bupropion, imipramin, maprotilin, venlafaxin stb.) és antipszichotikumok (például klórpromazin, klozapin stb.) [40]. A központi idegrendszeri laesióval bíró, illetve az alkoholt és tudatmódosító szereket (amfetamin, kokain, ketamin) abuzáló páciensek kontraszelekciója ajánlott még az előkészítés stádiumá- ban. A rohamok kialakulásának lehetősége miatt a rTMS-készülékek alkalmazásához a gyártók is feltüntetik kézikönyveikben a helyszínen előkészített antikonvulzív medikáció fontosságát, hangsúlyozva a kezelőszemélyzet felkészültségét ilyen esetekre. A kezeléssel kapcsolatos rohamok előfordulási gyakorisága becslések szerint 0,1\% [39]. Hosszú távú vizsgálatok nem mutattak a mellékhatásokkal kapcsolatban rizikónövekedést a kezelés folytatása során [41].

A fentiek (fejfájás, görcskészségfokozás) mellett hányinger, valamint szédülékenység, syncope jelentkezhet még a TMS-kezelés során. Még ritkább esetben hipomán vagy mániás epizód indukciója is előfordulhat.

\section{A kezelés kivitelezése}

A rTMS-kezelések alkalmazásakor négy fontos paramétert kell számba venni: a stimulálás helyét, intenzitását, frekvenciáját és a leadott ingerlések összesített mennyiségét. Minden kezelés a MT meghatározásával kezdődik, mely a motoros cortex aktiválásához szükséges mágneses térerôsséget jelenti. A MT-értéket az adott kérgi terület anatómiai viszonyain kívül számos élettani faktor befolyásolja (az alvás mennyisége, a kor, a napszak, a gyógyszerek), így egyéni varianciát mutat [42]. A kezelés során a későbbiekben használt ingererősség mértékét a motoros kérgen keresztül kiváltott, végtagi mioelektromos elektródával regisztrálható, izom-összehúzódást kiváltó legkisebb ingerlési intenzitáshoz viszonyítjuk [43]. A klinikai gyakorlatban legelterjedtebb célpont a bal DLPFC, bár ezen terület jobb hemisphaeriumi megfelelője is ígéretes területnek tûnik a major depressziós páciensek kezelésében. A klinikai gyakorlatban elterjedt célzási módszer a Talairach-atlasz adataira épül, amely a bal DLPFC-t öt centiméterrel pozicionálja a motoros kéregtől ventralisan [44]. Az ingerlés erősségének (avagy intenzitásának) elég nagynak kell lennie ahhoz, hogy a célzott régió neuronjait depolarizálja. A kezelések kezdetén meghatározott motoros határérték 120\%-a elegendő a kívánt depolarizáló hatás eléréséhez. Az ingerlések frekvenciája (amit Hz-ben adunk meg, másodpercenkénti ingerlésekre utalva) a depolarizáció eredő hatását fogja megszabni: alacsony frekvencia mellett ( $1 \mathrm{~Hz}$ vagy kevesebb) inhibitoros választ várhatunk, magas frekvenciánál (1 Hz fölött) a stimulált régió ingerlékenysége fokozódik. A nemzetközi ajánlások a major depresszió kezelésében a 10-20 Hz-es frekvenciát adják meg mint standard beállítást [45]. A kezelések időtartama határozza meg a leadott impulzusok mennyiségét. Átlagosan egy kezelés során 75 sorozatban 4-4 másodperc alatt 3000 impulzus éri összesen az agyat, a terápiás alkalmakat pedig heti ötször ismétlik, 4-6 héten keresztül [18]. Bár a szakirodalomban található kutatások az ingerlés erôsségében, az ismétlésszámban és a terápiás ülések számában nagy szórást mutatnak, metaanalízisek szerint a kezelésre javulást mutató betegek száma jelentősen növekszik, amennyiben az ülések száma több, mint 10, az intenzitás 
nagyobb, mint a MT-érték 100\%-a, és az egy alkalommal alkalmazott ingerlések száma több, mint 1000 [46].

A magyar nyelvü szakmai irodalomban 2016-ban jelent meg közlemény a TMS terápiás alkalmazásáról major depresszióban [47]. Az akkor még csak kitekintésben megemlített théta-frekvenciájú ingerlés (theta burst stimulation, TBS) 2018-ban megkapta a klinikai használatához szükséges jóváhagyást az FDA-tól. A TBS-protokoll magas frekvenciájú, $10 \mathrm{~Hz}$-es intermittáló ingerléssel (4 másodpercen keresztül ingerlés, 26 másodperc szünet) stimulálja a DLPFC-t 120\%-os MT-vel, 3 percen keresztül, 3000 leadott impulzusig, így a standard kezelési eljáráshoz képest jóval rövidebb idő a kivitelezése. Major depresszióval diagnosztizált pácienseknél a kezelés szignifikáns tüneti javulással járt (49\%-os válaszráta mellett 32\%-os remisszió), mellékhatásai pedig megegyeztek a hagyományos eljárásnál ismertetettekkel [48]. A TBS-protokoll alkalmazásával kapcsolatban merült fel még preklinikai fázisban a megfigyelés, miszerint a $\mathrm{D}_{2}$ receptorok gátlása rontja a rTMS-kezelés hatékonyságát. A kérdés tisztázására irányuló vizsgálat azonban a fentieknek pontosan az ellenkezőjét igazolta: a vizsgált antipszichotikus kezelésben részesülő, TBS-protokoll szerint kezelt páciensek esetén jobb válaszarányt és magasabb remissziós rátát igazoltak (nem szignifikáns mértékben), mint a gyógyszeres terápiában nem részesülők esetén [49]. Fontos tanulság, hogy az alkalmazott antipszichotikus kezelés nem ront a rTMS-kezelés várható hatékonyságán.

\section{Neuronavigáció}

Tekintettel arra, hogy jelentős anatómiai variancia állhat fenn személyek között, a Talairach-atlasz által nyújtott becslés nem mindig a megcélozni kívánt területre mutat pontosan [50], így felmerül, hogy pontosabb célzás esetén kedvezőbb remissziós rátával járhat a kezelés. Ennek tudatában logikus lépés volt a TMS-készülékek fejlesztésében, amikor az ingerlést végző rendszert összekapcsolták egy számítógéppel, amelyen a vizsgálati alanyról készült MR-felvételen valós időben lehet követni az ingerlés pontos helyzetét, térbeli helymeghatározó eszközök segítségével, melyeket a rTMS-készülék tekercsén és a páciensen helyeztek el. Ezen rendszereket neuronavigációs készülékeknek hívjuk. Segítségükkel a kezelő pár milliméteres pontossággal célozhat, számításba véve a cortex és az ingerlőtekercs közötti anatómiai struktúrák mágneses teret gyengítő hatását [51]. Továbbá a MRalaptérkép funkcionális és perfúziós adatokkal is rendelkezhet, illetve az ingerelt mezőt mint ROI-t használva, annak kapcsolatrendszere traktográfiával elemezhető.

Bár a hagyományos és a neuronavigációval végzett rTMS-kezelés hatékonyságát összehasonlító vizsgálatok száma eddig csekély, egy kutatás során MDZ miatt kezelt páciensek neuronavigációs rendszerrel pontosan a bal DLPFC-régió területén részesültek kezelésben, míg a másik betegcsoportot ezen a területen kívül ingerelték.
Az utóbbi betegcsoport nem mutatott a MADRS skálán észlelhető javulást, ellentétben azokkal, akiknél pontos lokalizációban történt a kezelés [52].

\section{Kiegészítő terápiás lehetőségek}

Az FDA általi jóváhagyás a rTMS-monoterápiát javasolja, antidepresszív gyógyszeres kiegészítés nélkül. Emellett a klinikai gyakorlat a legtöbb helyen az orális antidepresszív medikációval kombinált kezelést részesíti előnyben [40]. A jelenlegi szakmai konszenzus nem zárja ki a pszichotrop gyógyszeres kiegészítést, mivel eddig nem találtak bizonyítékot nem kívánt hatások gyakoribb előfordulására a kombinált rTMS-antidepresszív terápiák esetén [53]. A rTMS-kezeléssel párhuzamosan alkalmazott gyógyszeres terápia hatékonyságára hívja fel a figyelmet az a 2016. évi vizsgálat, mely kimutatta, hogy míg az antidepresszív terápiában részesülő páciensek 47,8\%-a mutatott választ a kezelésre, addig a gyógyszermentes vizsgálati alanyoknál ez az arány csak 36,6\% volt [54]. Az antipszichotikus medikációban részesülő csoport és az antipszichotikumot nem szedő csoport válaszaránya között nem volt érdemi különbség [49]. A fenti eredmények értékelésekor azonban figyelembe kell venni azt is, hogy a gyógyszermentes csoport tagjainál lehetséges, hogy a korábban hatástalannak bizonyult terápiák felfüggesztése eleve rosszabb prognózissal járó betegeknél történt meg [54].

A mély rTMS-kezelés mint kiegészítő kezelés a gyógyszeres terápia mellett $\mathrm{MDZ}$ miatt kezelt betegek esetén 70,6\%-os válaszaránnyal és 41,2\%-os remisszióval járt (a vizsgálat 17 ambuláns beteg bevonásával készült, s a szorongás és a szuicid gondolatok terén is jelentős javulást mutatott a vizsgálat kezdetéhez képest). Az eredmények tükrében felmerül a lehetőség, hogy a mágneses kezelés gyorsítja, illetve javítja a válaszkészséget az antidepresszív kezelésre [55]. A rTMS-kezelés lezárását követő fenntartó antidepresszív farmakoterápiára egyelőre nincs nemzetközileg elfogadott ajánlás, így ajánlott az egyéb helyzetben folytatott antidepresszív terápia alapelvei szerint eljárni.

A rTMS-kezelés mellett alkalmazott pszichoterápia hatékonysága és helye a klinikai gyakorlatban egyelőre tisztázatlan kérdést jelent. A témakörben egyelöre csak esettanulmányokat publikáltak, egységes, szervezett kutatások még nem folytak róla. Egy esettanulmány beszámolója szerint sikeresen alkalmaztak kognitív viselkedésterápiát TRD miatt rTMS-kezelésen részt vett betegnél [56]. Fontos még kiemelni a kiegészítő pszichoterápia kérdéskörében annak lehetőségét, hogy a terápiás ülés és a rTMS-kezelés elviekben történhet egyszerre, ami időt takarítana meg (és esetlegesen az adherenciát javítaná) az amúgy időigényes kezelésnél. A szakirodalom a TMSkezelés közben folytatott pszichoterápiát „online”, a külön alkalmazottat pedig „offline” terápiának nevezi. Tisztázandó kérdés, hogy az ily módon „online” alkalmazott pszichoterápia is eredményesnek bizonyul-e, 
vagy a zavaró körülmények és a neurofiziológiai változások kizárják, hogy párhuzamosan történjen a két eljárás, vagy épp ellenkezőleg, a két kezelés egyszerre történő alkalmazása járhat-e additív hatással.

\section{Következtetés}

Az antidepresszív terápiára nem megfelelően reagáló MDZ és a TRD kezelésében a rTMS reményteli és biztonságos alternatívának tünik, akár monoterápiában, akár antidepresszív kezeléssel kombináltan. A neuronavigációs rendszerek hatékonyabb mivoltát célzó kutatások a jövőben segíthetnek tovább pontosítani ismereteinket a depresszió neurofiziológiájával kapcsolatban is, és tovább javíthatják a MDZ és TRD miatt kezelt páciensek terápiásválasz-arányát. A jövőben a rTMS - kedvező hatás-mellékhatás profilját is figyelembe véve - alkalmazásának további térhódítása várható, és a depresszív zavarok mellett más pszichiátriai és neurológiai kórképekben és tünetekben is várhatóan sikerrel alkalmazhatóvá válik.

Anyagi támogatás: A közlemény megírása, illetve a kapcsolódó kutatómunka anyagi támogatásban nem részesült.

Szerzői munkamegosztás: P. R., T. T., V. V., K. N., Z. A., S. G.: Irodalomkutatás. P. R., V. V., T. T.: A kézirat megszövegezése. K. N., B. A., Z. A., O. P., F. S., S. G.: Lektorálás, szakmai konzultáció. A cikk végleges változatát valamennyi szerző elolvasta és jóváhagyta.

Érdekeltségek: A szerzőknek nincsenek érdekeltségeik.

\section{Köszönetnyilvánítás}

T. T. a Nemzeti Agykutatási Program (KTIA-13-NAP-A-II/12; 2018-2022) és a Kiválósági Centrum Pályázat (2019-2020) támogatásával dolgozik.

\section{Irodalom}

[1] Barker AT, Jalinous R, Freeston IL. Non-invasive magnetic stim ulation of human motor cortex. Lancet 1985; 325: 1106-1107.

[2] Uozumi T, Tsuji S, Murai Y. Motor potentials evoked by magnetic stimulation of the motor cortex in normal subjects and patients with motor disorders. Electroencephalogr Clin Neurophysiol. 1991; 81: 251-256.

[3] Davey K, Epstein CM. Magnetic stimulation coil and circuit design. IEEE Trans Biomed Eng. 2000; 47: 1493-1499.

[4] Deng ZD, Lisanby SH, Peterchev AV. Electric field depth-focality tradeoff in transcranial magnetic stimulation: simulation comparison of 50 coil designs. Brain Stimul. 2013; 6: 1-13.

[5] Bersani FS, Minichino A, Enticott PG. Deep transcranial magnetic stimulation as a treatment for psychiatric disorders: a comprehensive review. Eur Psychiatry 2013; 28: 30-39.

[6] Chen R, Classen J, Gerloff C, et al. Depression of motor cortex excitability by low-frequency transcranial magnetic stimulation. Neurology 1997; 48: 1398-1403.
[7] Pascual-Leone A, Valls-Solé J, Wassermann E. Responses to rapid-rate transcranial magnetic stimulation of the human motor cortex. Brain 1994; 117: 847-858.

[8] Greicius MD, Flores BH, Menon V, et al. Resting-state functional connectivity in major depression: abnormally increased contributions from subgenual cingulate cortex and thalamus. Biol Psychiatry 2007; 62: 429-437.

[9] Mayberg HS. Modulating dysfunctional limbic-cortical circuits in depression: towards development of brain-based algorithms for diagnosis and optimised treatment. Br Med Bull. 2003; 65: 193-207.

[10] Drevets WC, Price JL, Furey ML. Brain structural and functional abnormalities in mood disorders: implications for neurocircuitry models of depression. Brain Struct Funct. 2008; 213: 93-118.

[11] Schutter DJ. Antidepressant efficacy of high-frequency transcranial magnetic stimulation over the left dorsolateral prefrontal cortex in double-blind sham-controlled designs: a meta-analysis. Psychol Med. 2009; 39: 65-75.

[12] Schutter DJ. Quantitative review of the efficacy of slow-frequency magnetic brain stimulation in major depressive disorder. Psychol Med. 2010; 40: 1789-1795.

[13] Murrough JW, Iacoviello B, Neumeister A, et al. Cognitive dysfunction in depression: neurocircuitry and new therapeutic strategies. Neurobiol Learn Mem. 2011; 96: 553-563.

[14] Mayberg HS, Liotti M, Brannan SK, et al. Reciprocal limbiccortical function and negative mood: converging PET findings in depression and normal sadness. Am J Psychiatry 1999; 156: 675-682.

[15] Gur E, Lerer B, Dremencov E, et al. Chronic repetitive transcranial magnetic stimulation induces subsensitivity of presynaptic serotonergic autoreceptor activity in rat brain. Neuroreport 2000; 11: 2925-2929.

[16] Keck ME, Welt T, Post A, et al. Neuroendocrine and behavioral effects of repetitive transcranial magnetic stimulation in a psychopathological animal model are suggestive of antidepressantlike effects. Neuropsychopharmacology 2001; 24: 337-349.

[17] Post A, Müller MB, Engelmann M, et al. Repetitive transcranial magnetic stimulation in rats: evidence for neuroprotective effects in vitro and in vivo. Eur J Neurosci. 1999; 11: 3247-3254.

[18] O'Reardon JP, Solvason HB, Janicak PG. Efficacy and safety of transcranial magnetic stimulation in the acute treatment of major depression: a multisite randomized controlled trial. Biol Psychiatry $2007 ; 62$ : 1208-1216.

[19] Shawn M, Irving MR, Linda LC, et al. Consensus recommendations for the clinical application of repetitive transcranial magnetic stimulation (rTMS) in the treatment of depression. J Clin Psychiatry 2018; 79(1): 16cs10905.

[20] Levkovitz Y, Isserles M, Padberg F, et al. Efficacy and safety of deep transcranial magnetic stimulation for major depression: a prospective multicenter randomized controlled trial. World Psychiatry 2015; 14: 64-73.

[21] Nguyen K-H, Gordon LG. Cost-effectiveness of repetitive transcranial magnetic stimulation versus antidepressant therapy for treatment-resistant depression. Value Health 2015; 18: 597604.

[22] Simpson KN, Welch MJ, Kozel FA, et al. Cost-effectiveness of transcranial magnetic stimulation in the treatment of major depression: a health economics analysis. Adv Ther. 2009; 26: 346368.

[23] Voigt J, Carpenter L, Leuchter A. Cost effectiveness analysis comparing repetitive transcranial magnetic stimulation to antidepressant medications after a first treatment failure for major depressive disorder in newly diagnosed patients - a lifetime analysis. PLOS ONE 2017; 12: e0186950.

[24] Greden JF, Riba MB, McInnis MG, et al. Treatment resistant depression: a roadmap for effective care. American Psychiatric Publishing, Arlington, VA, 2011; pp. 3. 
[25] Berlim MT, Turecki G. Definition, assessment, and staging of treatment-resistant refractory major depression: a review of current concepts and methods. Can J Psychiatry 2007; 52: 46-54.

[26] Warden D, Rush AJ, Trivedi $M H$, et al. The STAR*D project results: a comprehensive review of findings. Curr Psychiatry Rep. 2007; 9: 449-459.

[27] Philip NS, Dunner DL, Dowd SM, et al. Can medication free, treatment-resistant, depressed patients who initially respond to TMS be maintained off medications? A prospective, 12-month multisite randomized pilot study. Brain Stimul. 2016; 9: 251257.

[28] Pal E, Nagy F, Achermann Z, et al. The impact of left prefrontal repetitive transcranial magnetic stimulation on depression in Parkinson's disease: a randomized, double-blind, placebo-controlled study. Mov Disord. 2010; 25: 2311-2317.

[29] Wall CA, Croarkin PE, Sim LA, et al. Adjunctive use of repetitive transcranial magnetic stimulation in depressed adolescents: a prospective, open pilot study. J Clin Psychiatry 2011; 72: 12631269.

[30] Kim DR, Epperson N, Paré E, et al. An open label pilot study of transcranial magnetic stimulation for pregnant women with major depressive disorder. J Womens Health 2011; 20: 255-261.

[31] Harel EV, Zangen A, Roth Y, et al. H-coil repetitive transcranial magnetic stimulation for the treatment of bipolar depression: an add-on, safety and feasibility study. World J Biol Psychiatry 2011; 12: 119-126.

[32] Barr MS, Farzan F, Tran LC, et al. A randomized controlled trial of sequentially bilateral prefrontal cortex repetitive transcranial magnetic stimulation in the treatment of negative symptoms in schizophrenia. Brain Stimulat. 2012; 5: 337-346.

[33] Rostami R, Kazemi R, Nitsche MA, et al. Clinical and demographic predictors of response to rTMS treatment in unipolar and bipolar depressive disorders. Clin Neurophysiol. 2017; 128: 1961-1970.

[34] Dlabac-de Lange JJ, Liemburg EJ, Bais L, et al. Effect of bilateral prefrontal rTMS on left prefrontal NAA and Glx levels in schizophrenia patients with predominant negative symptoms: an exploratory study. Brain Stimul. 2017; 10: 59-64.

[35] Rossi S, Hallett M, Rossini PM, et al., The Safety of TMS Consensus Group. Safety, ethical considerations, and application guidelines for the use of transcranial magnetic stimulation in clinical practice and research. Clin Neurophysiol. 2009; 120: 2008-2039.

[36] Hsieh TH, Dhamne SC, Chen JJ, et al. Minimal heating of aneurysm clips during repetitive transcranial magnetic stimulation. Clin Neurophysiol. 2012; 123: 1471-1473.

[37] Deng ZD, Lisanby SH, Peterchev AV. Transcranial magnetic stimulation in the presence of deep brain stimulation implants: induced electrode currents. Conf Proc IEEE Eng Med Biol Soc. 2010; 2010: 6821-6824.

[38] Janicak PG, O'Reardon JP, Sampson SM, et al. Transcranial magnetic stimulation in the treatment of major depressive disorder: a comprehensive summary of safety experience from acute exposure, extended exposure, and during reintroduction to treatment. J Clin Psychiatry 2008; 69: 222-232.

[39] Dobek CE, Blumberger DM, Downar J, et al. Risk of seizures in transcranial magnetic stimulation: a clinical review to inform consent process focused on bupropion. Neuropsychiatr Dis Treat. 2015; $11: 2975-2987$.

[40] Bermudes RA, Lanocha KI, Janicak PG. Transcranial magnetic stimulation: clinical applications for psychiatric practice. American Psychiatric Publishing, Arlington, VA, 2017.

[41] Dunner DL, Aaronson ST, Sackeim HA, et al. A multisite, naturalistic, observational study of transcranial magnetic stimulation for patients with pharmacoresistant major depressive disorder: durability of benefit over a 1-year follow-up period. J Clin Psychiatry 2014; 75: 1394-1401.

[42] Sommer M, Wu T, Tergau F, et al. Intra- and interindividual variability of motor responses to repetitive transcranial magnetic stimulation. Clin Neurophysiol. 2002; 113: 265-269.

[43] Awiszus A. TMS and threshold hunting. Suppl Clin Neurophysiol. 2003 ; 56: 13-23.

[44] Talairach J, Tournoux P. Co-planar stereotaxic atlas of the human brain. Thieme, Stuttgart, 1988.

[45] Lefaucheur J-P, André-Obadia N, Antal A. Evidence-based guidelines on the therapeutic use of repetitive transcranial magnetic stimulation (rTMS). Clin Neurophysiology 2014; 125: 2150-2206.

[46] Berlim MT, Van den Eynde F, Daskalakis J. Clinically meaningful efficacy and acceptability of low-frequency repetitive transcranial magnetic stimulation (rTMS) for treating primary major depression: a meta-analysis of randomized, double-blind and shamcontrolled trials. Neuropsychopharmacology 2013; 38: 543551.

[47] Németh VL, Csifcsák G, Kincses ZT, et al. The terapeutic use of transcranial magnetic stimulation in major depression. [Transcranialis mágneses stimuláció terápiás alkalmazása major depresszióban]. Ideggyógy Szle. 2016; 69: 89-97. [Hungarian]

[48] Blumberger DM, Vila-Rodriguez F, Thorpe KE, et al. Effectiveness of theta burst versus high-frequency repetitive transcranial magnetic stimulation in patients with depression (THREE-D): a randomised non-inferiority trial. Lancet 2018; 391: 1683-1692.

[49] Schulze L, Remington G, Giacobbe P, et al. Effect of antipsychotic pharmacotherapy on clinical outcomes of intermittent theta-burst stimulation for refractory depression. J Psychopharmacol. 2017; 31: 312-319.

[50] Herwig U, Padberg F, Unger J, et al. Transcranial magnetic stimulation in therapy studies: examination of the reliability of "standard" coil positioning by neuronavigation. Biol Psychiatry 2001; 50: 58-61.

[51] Schönfeldt-Lecuona C, Lefaucheur J-P, Cardenas-Morales L, et al. The value of neuronavigated rTMS for the treatment of depression. Neurophysiol Clin. 2010; 40: 37-43.

[52] Paillère Martinot ML, Galinowski A, Ringuenet D, et al. Influence of prefrontal target region on the efficacy of repetitive transcranial magnetic stimulation in patients with medication-resistant depression: a $\left[{ }^{18} \mathrm{~F}\right]$-fluorodeoxyglucose-PET and MRI study. Int J Neuropsychopharmacol. 2010; 13: 45-59.

[53] Perera T, George MS, Grammer G, et al. The Clinical TMS Society consensus review and treatment recommendations for TMS therapy for major depressive disorder. Brain Stimul. 2016; 9: 336-346.

[54] Fitzgerald PB, Hoy KE, Anderson RJ, et al. A study of the pattern of response to rTMS treatment in depression. Depress Anxiety 2016; 33: 746-753.

[55] Berlim MT, Van den Eynde F, Tovar-Perdomo S, et al. Augmenting antidepressants with deep transcranial magnetive stimulation (DTMS) in treatment-resistant major depression. World J Biol Psychiatry 2014; 15: 570-578.

[56] Vedeniapin A, Cheng L, George MS. Feasibility of simultaneous cognitive behavioral therapy and left prefrontal rTMS for treatment resistant depression. Brain Stimulat. 2010; 3: 207-210.

(Pilisi Róbert dr.,

Pécs, Rét u. 2., 7623

e-mail: robert.pilisi@gmail.com)

A cikk a Creative Commons Attribution 4.0 International License (https://creativecommons.org/licenses/by/4.0/) feltételei szerint publikált Open Access közlemény, melynek szellemében a cikk bármilyen médiumban szabadon felhasználható, megosztható és újraközölhető, feltéve, hogy az eredeti szerző és a közlés helye, illetve a CC License linkje és az esetlegesen végrehajtott módositások feltüntetésre kerülnek. (SID_1) 